\title{
Hydro-physical properties of soil and pasture vegetation coverage under animal trampling
}

\author{
Pedro H. D. Batista ${ }^{1}$, Gledson L. P. de Almeida ${ }^{2}$, Jhon L. B. da Silva ${ }^{1}$, Frederico A. C. Lins ${ }^{1}$, \\ Marcos V. da Silva ${ }^{1} \&$ Jose J. F. Cordeiro Junior ${ }^{3}$
}

\begin{abstract}
${ }^{1}$ Universidade Federal Rural de Pernambuco/Programa de Pós-Graduação em Engenharia Agrícola, Recife, PE, Brasil. E-mail: giga_pedro@hotmail.com (Corresponding author) - ORCID: 0000-0002-8710-5678; jhonlennoigt@hotmail.com - ORCID: 0000-0002-2611-4036; frederico_acl@hotmail.com ORCID: 0000-0001-6498-9805; marcolino_114@hotmail.com - ORCID: 0000-0002-1318-2320

${ }^{2}$ Universidade Federal Rural de Pernambuco/Departamento de Engenharia Agrícola. Recife, PE, Brasil. E-mail: gledson81@hotmail.com - ORCID: 0000-0002-5813-4517

${ }^{3}$ Universidade Federal de Sergipe/Núcleo de Graduação de Agronomia.Nossa Senhora da Glória, SE, Brasil. E-mail: jairofcordeiro@hotmail.com - ORCID: 0000-0002-1138-8309
\end{abstract}

\begin{abstract}
Soil compaction and pasture degradation are often due to the pressure exerted by the animals' hooves. In this sense, this study aimed to verify possible changes in the soil and changes in the pasture vegetation coverage due to animal trampling. Thus, a study was carried out on a farm in the 'Agreste' region of Pernambuco, Brazil. Soil samples were collected before and after the grazing period, with 36 points regularly distributed in an area of $40 \times 40 \mathrm{~m}$ managed under continuous grazing, with a stocking rate of $12 \mathrm{AU} \mathrm{ha}^{-1}$. At each point, density, total porosity, humidity, and penetration resistance of the soil at a depth of 0-0.10 m, as well as hydraulic conductivity and organic matter in the soil surface, were determined. Before and after grazing, images from the Sentinel-2A satellite were also obtained to observe the response pattern of pasture vegetation over time using the Normalized Difference Vegetation Index (NDVI) and Pasture Vegetation Coverage (PVC). The physical-hydric attributes of the soil were subjected to factor analysis. NDVI and PVC maps were evaluated for spatial variability. After the grazing period, there was a change in the attributes of the soil under study due to the animal trampling. Remote sensing (NDVI and PVC) highlighted patterns of variation, such as the reduction of pasture and possible areas of preference for the animals.
\end{abstract}

Key words: factorial analysis, soil compaction, remote sensing

\section{Propriedades físico-hídricas do solo e cobertura vegetal de pastagens sob pisoteio animal}

RESUMO: A compactação do solo e a degradação das pastagens muitas vezes são provenientes da pressão exercida pelo casco dos animais. Nesse sentido, objetivou-se verificar possíveis modificações no solo e mudanças na cobertura vegetal da pastagem devido ao pisoteio animal. Assim, um estudo foi realizado em uma fazenda na região do Agreste de Pernambuco, Brasil. Em uma área de $40 \times 40 \mathrm{~m}$ manejada sob pastejo contínuo, com uma taxa de lotação de $12 \mathrm{UA} \mathrm{ha}^{-1}$; as amostras de solo foram coletadas antes e após o período de pastejo, com 36 pontos distribuídos regularmente. Em cada ponto, determinou-se a densidade, porosidade total, umidade e resistência à penetração do solo na profundidade de $0-0,10 \mathrm{~m}$, bem como a condutividade hidráulica e a matéria orgânica na superfície do solo. Antes e após o pastejo, imagens do satélite Sentinel-2A também foram obtidas para observar o padrão de resposta da vegetação da pastagem ao longo do tempo por meio do Índice de Vegetação por Diferença Normalizada (NDVI) e Cobertura Vegetal de Pastagem (CVP). Os atributos físico-hídricos do solo foram submetidos a análise fatorial. Os mapas de NDVI e CVP foram avaliados quanto à variabilidade espacial. Após o período de pastejo, houve alteração nos atributos do solo em estudo devido ao pisoteio dos animais. O sensoriamento remoto (NDVI e CVP) destacou padrões de variação, como a redução da pastagem e possíveis áreas de preferencias dos animais.

Palavras-chave: análise fatorial, compactação do solo, sensoriamento remoto 


\section{INTRODUCTION}

With 221.81 million head of cattle in 2018, Brazil occupies a prominent position, with the largest cattle herd in the world. According to the Brazilian Association of Meat Exporting Industries, the State of Pernambuco ranks fourth among the states with the largest herd in the Northeast Region (ABIEC, 2018).

Therefore, the impact caused by the trampling of animals, mainly by cattle, is one of the main agents that cause soil compaction causing a productivity reduction of the pastures, mainly related to the physical degradation of the soil (Pulido et al., 2017). Thus, the compaction caused by cattle alters the hydro-physical attributes of the soil, such as the reduction of porosity and the soil infiltration rate, besides the increase in the bulk density (van Klink et al., 2015; Niu et al., 2017).

Given the possible impacts caused on grazed fields, the use of remote sensing techniques for spatial monitoring of changes in pasture areas, especially when using vegetation indexes such as the Normalized Difference Vegetation Index (NDVI) and the Pasture Vegetation Coverage (PVC), present themselves as essential allies in monitoring the response patterns of pasture vegetation cover, important mainly for the assessment of environmental degradation (Oldoni et al., 2019).

In this context, the use of remote sensing techniques in conjunction with information on soil attributes can help to make management decisions to reduce the negative environmental impact of agriculture and livestock (Bernardi et al., 2017).

Aiming to propose and guide appropriate management in pasture fields, the study aimed to verify changes in the hydro- physical properties in the soil and changes in the pasture vegetation coverage due to animal trampling.

\section{Material ANd Methods}

The study area is located in the municipality of Capoeiras (Figure 1), Agreste region, dairy basin, of State of Pernambuco, Brazilian semiarid, between the parallels of $08^{\circ} 37^{\prime} 10.27^{\prime \prime} \mathrm{S}$ (UTM: $9046392 \mathrm{~m}$ ) and 08³7'11.82" S (UTM: $9046344 \mathrm{~m}$ ), and between the meridians of $36^{\circ} 36^{\prime} 46.50^{\prime \prime} \mathrm{W}$ (UTM: $762715 \mathrm{~m}$ ) and $36^{\circ} 36^{\prime} 47.98^{\prime \prime} \mathrm{W}$ (UTM: $762670 \mathrm{~m}$ ), with an altitude of $800 \mathrm{~m}$.

According to the Köppen climate classification, the region's climate is characterized as semi-arid (Bsh), and the region's average annual rainfall is $588 \mathrm{~mm}$. The soil was classified as Alfisol. The fractions of sand, silt, and clay were determined by the densimeter method according to the methods described by EMBRAPA (Donagema et al., 2011) (Table 1).

Table 1. Physical characterization of the study area in Capoeiras, PE, Brazil

\begin{tabular}{|lc|}
\hline \multicolumn{1}{|c|}{ Attributes } & Values \\
\hline Layer & $0-0.10 \mathrm{~m}$ \\
\hline Slope $(\%)$ & 0 \\
\hline Textural class & Sandy loam \\
\hline Sand $\left(\mathrm{g} \mathrm{kg}^{-1}\right)$ & 817.82 \\
\hline Silt $\left(\mathrm{g} \mathrm{kg}^{-1}\right)$ & 178.78 \\
Clay $\left(\mathrm{g} \mathrm{kg}^{-1}\right)$ & 4.0 \\
\hline Particle density, Dp $\left(\mathrm{kg} \mathrm{dm}^{-3}\right)$ & 2.64 \\
\hline Bulk density $\left(\mathrm{g} \mathrm{cm}^{-3}\right)$ & 1.65 \\
\hline Organic matter $\left(\mathrm{g} \mathrm{kg}^{-1}\right)$ & 39.57 \\
\hline
\end{tabular}
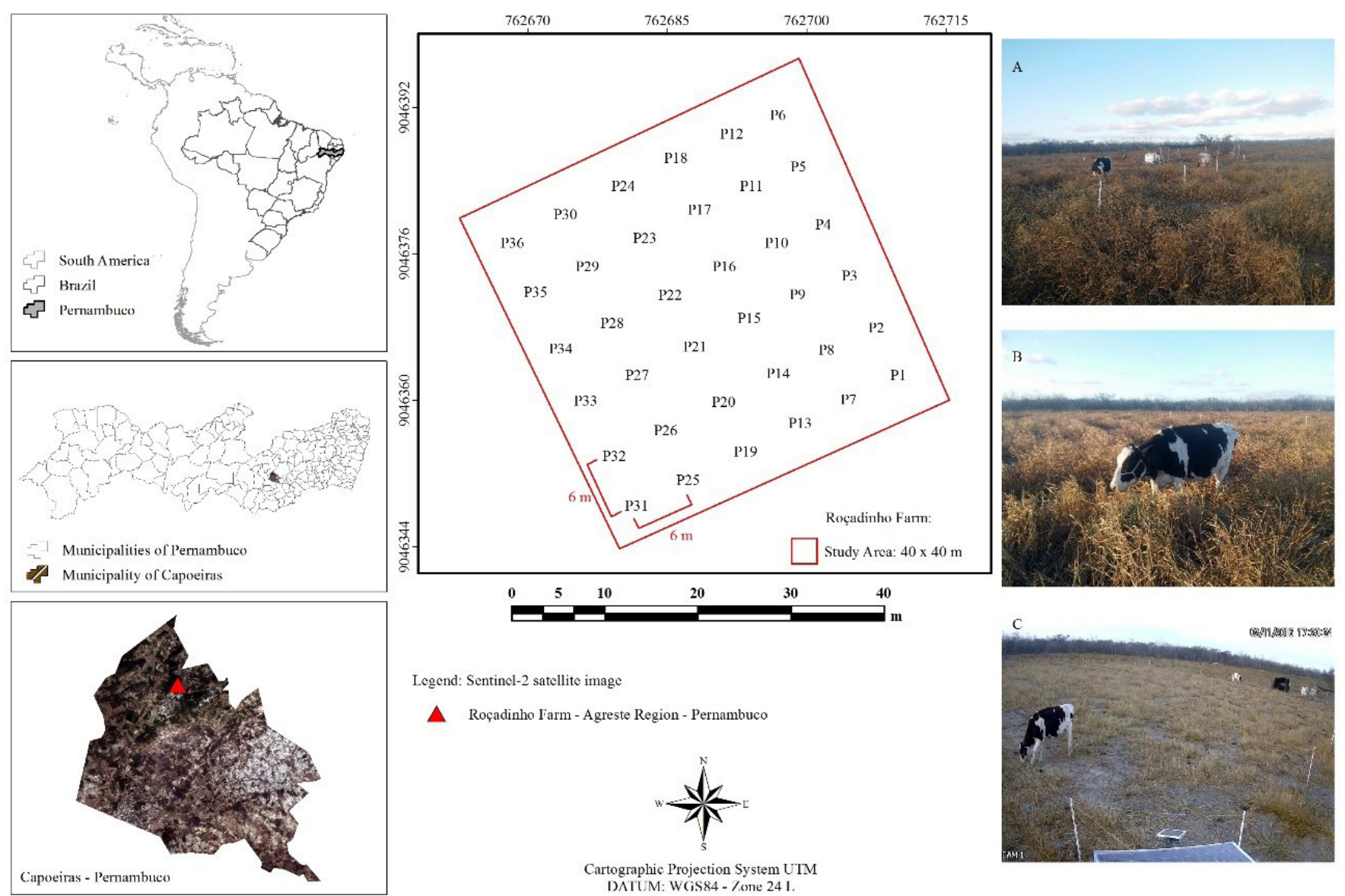

Figure 1. Spatial map of the location of the municipality of Capoeiras, PE, Brazil, of the study area on the Roçadinho farm, of the grazing field before $(\mathrm{A})$, during $(\mathrm{B})$, and after $(\mathrm{C})$ the grazing period 
The research was conducted during the spring, between $16 / 10$ and $5 / 11 / 2016$, totaling 21 consecutive days. The grazing field had dimensions of $40 \times 40 \mathrm{~m}$ (Figure 1). In the annex, there was a resting area for the animals, with dimensions of $8 \times 10 \mathrm{~m}$, containing a drinking fountain and a shadow area of approximately $16 \mathrm{~m}^{2}$.

The soil of the study area was prepared with a disc harrow before planting the grass. However, fertilization and soil correction were not used. The area also had no slope.

The management of a continuous grazing system, in soil under Brachiaria decumbens pasture, in rainfed cultivation was adopted. A stocking rate of $12 \mathrm{AU} \mathrm{ha}^{-1}$ was used, composed of heifers of the Girolando breed that started the grazing period with an average forage height of $0.90 \mathrm{~m}$, being suspended when an average height of $0.23 \mathrm{~m}$ was reached, as indicated by Fidalsk \& Alves (2015).

Thirty-six points were defined, in a regular grid of $6 \times 6 \mathrm{~m}$, in the grazing area (Figure 1), in which the penetration resistance, humidity, bulk density, total porosity, and density of soil particles in the $0-0.10 \mathrm{~m}$ layer was determined. Also, the saturated hydraulic conductivity and the organic matter content in the soil surface were evaluated.

Sampling was carried out before and after the grazing period; that is, the first sampling was carried out 120 days after the soil preparation and when the pasture was, on average, $0.90 \mathrm{~m}$ high. The second was carried out after 21 days of grazing. For undeformed soil collection, an Uhland-type sampler was used.

The undeformed soil samples were initially weighed to determine the wet weight of the soil and then dried in an oven at $105^{\circ} \mathrm{C}$ for $24 \mathrm{~h}$ to obtain the dry mass of the soil. Soil bulk density (Ds, $\mathrm{kg} \mathrm{dm}^{-3}$ ) was calculated from the weight of the kilndried soil and the total volume of the soil sample. The gravimetric water content $(\mathrm{Ug}, \%)$ was calculated by the difference between the wet weight and the dry weight of the sample obtained after drying in an oven. The particle density ( $\left.\mathrm{Dp}, \mathrm{kg} \mathrm{dm}^{-3}\right)$ was determined by the volumetric flask method. The total porosity $(\mathrm{Pt}, \%)$ was estimated using the Ds:Dp ratio. The organic matter content $\left(\mathrm{OM}, \mathrm{g} \mathrm{kg}^{-1}\right)$ was measured via oxidation with potassium dichromate in sulfuric acid. All procedures were performed, according to Donagema et al. (2011).

A reduced impact penetrometer, model IAA/Planalsucar/ Stolf, was used to determine penetration resistance of the soil (PR). With the number of $\mathrm{cm}$ per impact transformed into dynamic resistance $(\mathrm{MPa})$ using the Eq.1 proposed by Stolf (1991).

$$
P R=\frac{M+m+\left(\frac{M}{M+m} \cdot \frac{M \cdot h}{X}\right)}{A}
$$

where:

$\mathrm{PR}$ - penetration resistance of the soil, $\mathrm{kgf} \mathrm{cm}^{-2}\left(\mathrm{kgf} \mathrm{cm}^{-2}\right.$ $\times 0.098=\mathrm{MPa})$;

$\mathrm{M}$ - hammer mass, $1.6 \mathrm{~kg}$;

$\mathrm{m}$ - mass of the equipment without hammer, $1.5 \mathrm{~kg}$;

h - hammer drop height, $54 \mathrm{~cm}$;

$\mathrm{X}$ - penetration of the equipment stem, cm per impact; and, A - cone area, $1.35 \mathrm{~cm}^{2}$.
To characterize the infiltration of water in the soil, the Beerkan method was used, which is based mainly on simplified infiltration tests and on the analysis of the particle size distribution of the soil (Haverkamp et al., 1996; Lassabatere et al., 2006). The methodology developed by Bagarello et al. (2014) was used to determine the saturated hydraulic conductivity of the soil $\left(\mathrm{K} 0, \mathrm{~mm} \mathrm{~s}^{-1}\right)$, according to Eq. 2;

$$
\mathrm{K}_{0}=\frac{\mathrm{b}}{0.467\left(\frac{2.92}{\mathrm{r} \cdot \mathrm{a}}+1\right)}
$$

where:

$\mathrm{K}_{0} \quad$ - saturated hydraulic conductivity of the soil, $\mathrm{mm} \mathrm{s}^{-1}$;

b - angular coefficient of the line of the linearized equation of the infiltration function accumulated over time;

$\mathrm{r} \quad$ - ring radius of $75 \mathrm{~mm}$; and,

a $\quad-0.012$ was adopted, as suggested by Reynolds et al. (2002), for the use of permeameters and infiltrometers in soils that range from coarse sands to compacted clays.

Remote sensing techniques were introduced to aid, cross and consolidate terrestrial information for the spatial mapping of the study area, using two images from the Sentinel-2 satellite (processing level 2A) of the Multispectral Instrument (MSI) sensor and spatial resolution of $10 \mathrm{~m}$. This level of spatial detail highlights and discriminates objects on the Earth's surface with high capacity and efficiency, mainly on a smaller scale, as is the case with the $40 \times 40 \mathrm{~m}$ area of this research.

The images were made available by the European Space Agency (ESA) and obtained on the platform EOS/LandViewer (Earth Observing System), dated on 8/10/2016 (before grazing) and $7 / 11 / 2016$ (after grazing).

The digital and semi-automated processing of the images was performed using the ERDAS IMAGINE ${ }^{\circledR} 9.1$ Software, in which some steps of the SEBAL (Surface Energy Balance Algorithm for Land) algorithm were implemented, with which an iterative numerical procedure is performed according to the multispectral bands from the satellite, aiming to obtain thematic maps of the terrestrial surface (Bastiaanssen, 2000; Allen et al., 2002).

Therefore, the processing started with the stage of converting the gray levels of each multispectral band, converted to spectral radiance and monochromatic reflectance (level 2A) using calibration coefficients provided by the European Space Agency (ESA).

From the reflectance level $2 \mathrm{~A}$ product (corrected atmospheric product, including cloud tracking and correction of adjacency/slope effects), the multispectral bands of Sentinel2A images are a baseline for the geophysical parameters (Drusch et al., 2012; ESA, 2015; Fernández-Manso et al., 2016). Through the reflective bands, the Normalized Difference Vegetation Index (NDVI) was determined, according to Eq. 3 (Allen et al., 2002; Fernández-Manso et al., 2016).

$$
\mathrm{NDVI}=\frac{\mathrm{B}_{08}-\mathrm{B}_{04}}{\mathrm{~B}_{08}+\mathrm{B}_{04}}
$$


where:

NDVI - normalized difference vegetation index; and,

$\mathrm{B}_{08}$ e $\mathrm{B}_{04}$ - multispectral bands of near-infrared (NIR) and red (Red) bands of the Sentinel-2A satellite, respectively (ESA, 2015).

Subsequently, in order to highlight the level of susceptibility to soil degradation in the pasture area, the NDVI thematic map with its minimum and maximum values were used to obtain the pasture vegetation coverage index (PVC), according to Eq 4 (Gao et al., 2006).

$$
P V C=\frac{\mathrm{NDVI}^{-\mathrm{NDVI}_{\mathrm{s}}}}{\mathrm{NDVI}_{\mathrm{v}}+\mathrm{NDVI}_{\mathrm{s}}}
$$

where:

PVC - pasture vegetation coverage;

$\mathrm{NDVI}_{\mathrm{s}}$ - minimum value of the NDVI index observed among the pixels representing areas with exposed soil in the study area; and,

$\mathrm{NDVI}_{\mathrm{v}}$ - maximum value of the NDVI index found among the grazing area pixels.

The results of the measured soil attributes were subjected to factor analysis, which makes it possible to ascertain the greatest amount of original information contained in the variables and project the attributes that best explain the impact of animal trampling under the soil during the period under study.

The results of the NDVI vegetation index were analyzed using descriptive statistics: the measure of central tendency (mean) and dispersion (minimum, maximum, standard deviation - SD and coefficient of variation - CV). The NDVI thematic maps were evaluated for spatial variability, using CV values (\%), according to Warrick \& Nielsen (1980) criteria, with low variability - CV $<12 \%$; medium variability - $12 \%<$ $\mathrm{CV}<60 \%$ and high variability $-\mathrm{CV}>60 \%$.

\section{Results AND Discussion}

The factor analysis explained $59.21 \%$ of the total variability with two factors (F1 and F2, Figure 2A) for the moment before

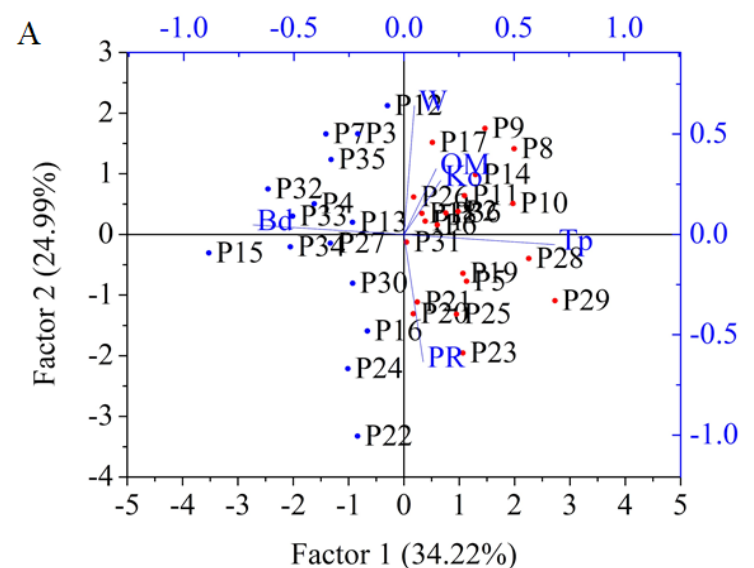

grazing. On the other hand, F1 and F2 explained $57.61 \%$ of the variability for the period after grazing (Figure 2B).

After grazing, the variables measured in the study exposed changes (Figure 2B), mainly those related to the volume of pores and the hydraulic conductivity of the soil, driven by positive relations between soil density and resistance to penetration, which occupied the opposite direction to total porosity, caused by the pressure exerted on the animals' hooves. That is, this result demonstrates that the cattle trampling in the pasture area compacted the soil at a depth of $0-0.10 \mathrm{~m}$ (Figures 2A and B).

This result corroborates Brito et al. (2018). They, in a pasture area of Brachiaria brizantha under Ultisol, with seven years of extensive grazing, observed that the association of penetration resistance influenced the aeration of the soil with the density in the surface layer, caused by the overgrazing.

These changes may favor the occurrence of runoff, erosion, and plant death; also, the reduction of soil porosity decreases water retention, aeration, affects the root development of plants, and increased nitrogen loss (Deon et al., 2018). Therefore, in the present study, the physical conditions of the soil showed changes, however, with little relation between the intrinsic attributes of the soil (organic matter content and texture), being more affected by the grazing system (stocking rate, duration of the grazing); thus, it is suggested that the stress applied with the animals' trampling was greater than the load capacity of the soil.

Therefore, as reported by Vasques et al. (2019), grazing affects the physical properties of the soil in greater proportions when the proper management of the grazing system, stocking rate, and forage offer are not considered for each situation.

However, Bonetti et al. (2015), when analyzing different stocking rates $\left(1.5 ; 2.5\right.$ and $\left.3.5 \mathrm{AU} \mathrm{ha}^{-1}\right)$ in clayey soil under Brachiaria decumbens pasture, reported that after 120 days of grazing, the cattle trampling was not enough to compact the soil at the evaluated grazing intensities.

Pasture vegetation ranged after the end of the research (Figure 3), highlighted by monitoring the normalized difference vegetation index (NDVI) before and after the grazing period, both in the minimum and maximum values and, especially, in the average values of spatial analysis (Table 2). It is worth

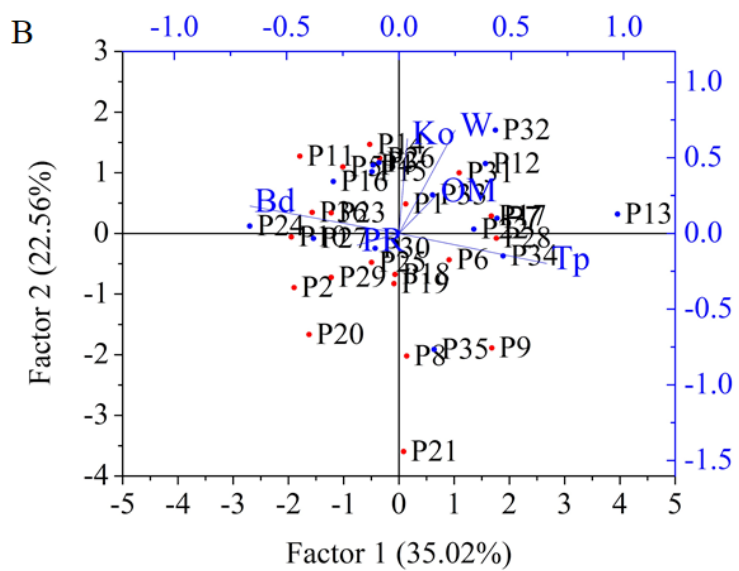

Ds - Soil bulk density; Pt - Total porosity; RP - Penetration resistance; Ug - Gravimetric humidity; $\mathrm{K}_{0}$ - Saturated hydraulic conductivity; MO - Organic matter

Figure 2. Dispersion of soil physico-hydric attributes: before (A) and after (B) grazing, based on the scores of the first (F1) and second (F2) factor 




Figure 3. Spatial distribution of the NDVI vegetation index in the pasture field, before (A) and after (B) grazing

Table 2. Clustering and dispersion measures of the NDVI vegetation index in the study area, before and after grazing

\begin{tabular}{cccccc}
\hline \multirow{2}{*}{ Date } & \multicolumn{5}{c}{ NDVI vegetation index } \\
\cline { 2 - 6 } & Minimum & Maximum & Average & ${ }^{1}$ SD & ${ }^{2}$ CV (\%) \\
\hline $8 / 10 / 2016$ & 0.18 & 0.30 & 0.25 & 0.03 & 12.0 \\
$7 / 11 / 2016$ & 0.10 & 0.15 & 0.12 & 0.01 & 8.33 \\
\hline
\end{tabular}

- Standard deviation, ${ }^{2}$ - Coefficient of variation

noting that monitoring via remote sensing confirmed the expected effect related to the reduction of vegetation, due to the management of continuous grazing for 21 uninterrupted days.

The NDVI (Figure 3A) presented low value before grazing (0.18) due to the vegetation of pasture in the semi-arid region showing a reflectance that is confused with that of the soil and mainly because it is an index sensitive to the green condition. The NDVI calculation does not adjust to decrease soil interference, as observed in other vegetation indexes. However, it is observed that this minimum value reduced even more when compared to Figure $3 \mathrm{~B}(0.10)$, at the end of grazing.

Therefore, the NDVI value was reduced to the point that its maximum value $(0.15$, Figure $3 \mathrm{~B})$ is below the minimum value $(0.18)$ of Figure $3 \mathrm{~A}$. This same pattern of behavior was observed, given the maximum values of the NDVI spatial analysis. Thus, it is demonstrated the rapid performance of animals in the pasture environment and the effectiveness of this type of spatial monitoring by orbital remote sensing.

However, the type of pasture vegetation coverage is in a dry condition, besides being in a semi-arid region, where pasture areas can be confused with sparse 'caatinga' vegetation and exposed soil.

It is also possible to observe from the class intervals of the NDVI thematic maps (Figure 3 ) the areas with the highest productivity of the pasture and, also, the probable grazing preference sites, according to the reduction of the vegetation index. However, these areas possibly received higher grazing pressure from the animals, which may favor compaction. These findings corroborate Manning et al. (2017), who report a preference of animals for areas with greater pasture biomass. However, one must also consider the irregular growth of the pasture vegetation itself, which may have been reflected in the spatial analysis.

The NDVI thematic maps showed a pattern of the spatial behavior of low variability, confirmed by the CV values, between 8.33 and $12.00 \%$, as highlighted in Table 2 .

The results of the factor analysis and remote sensing obtained are confirmed by Batista et al. (2019) in a study of the spatial variability of the soil physical attributes, in the same area of the present research. The authors observed that after 21 days of grazing, the physical attributes of the analyzed soil were altered by the action of animal trampling, mainly in the eastern region of the paddock, where according to the NDVI maps (Figures $3 \mathrm{~A}$ and $\mathrm{B}$ ), this region had the highest values $(0.27-0.30)$ for the period before grazing and the vegetation in this area was highly reduced $(0.12-0.15)$, which may indicate a preferred grazing area.

The spatialization of the pasture vegetation coverage (PVC) highlights, through the thematic maps, the gradual intensity of grazing of the animals over the days (Figure 4). Continuous grazing management and animal trampling affect the soil's physical properties, modifying the structure and, consequently, favoring soil compaction in the productive environment, thus decreasing grazing productivity and quality (Bernardi et al., 2017).

Similar results were found by Zhang et al. (2017) in a study of the effects of grazing on the characteristics of vegetation 


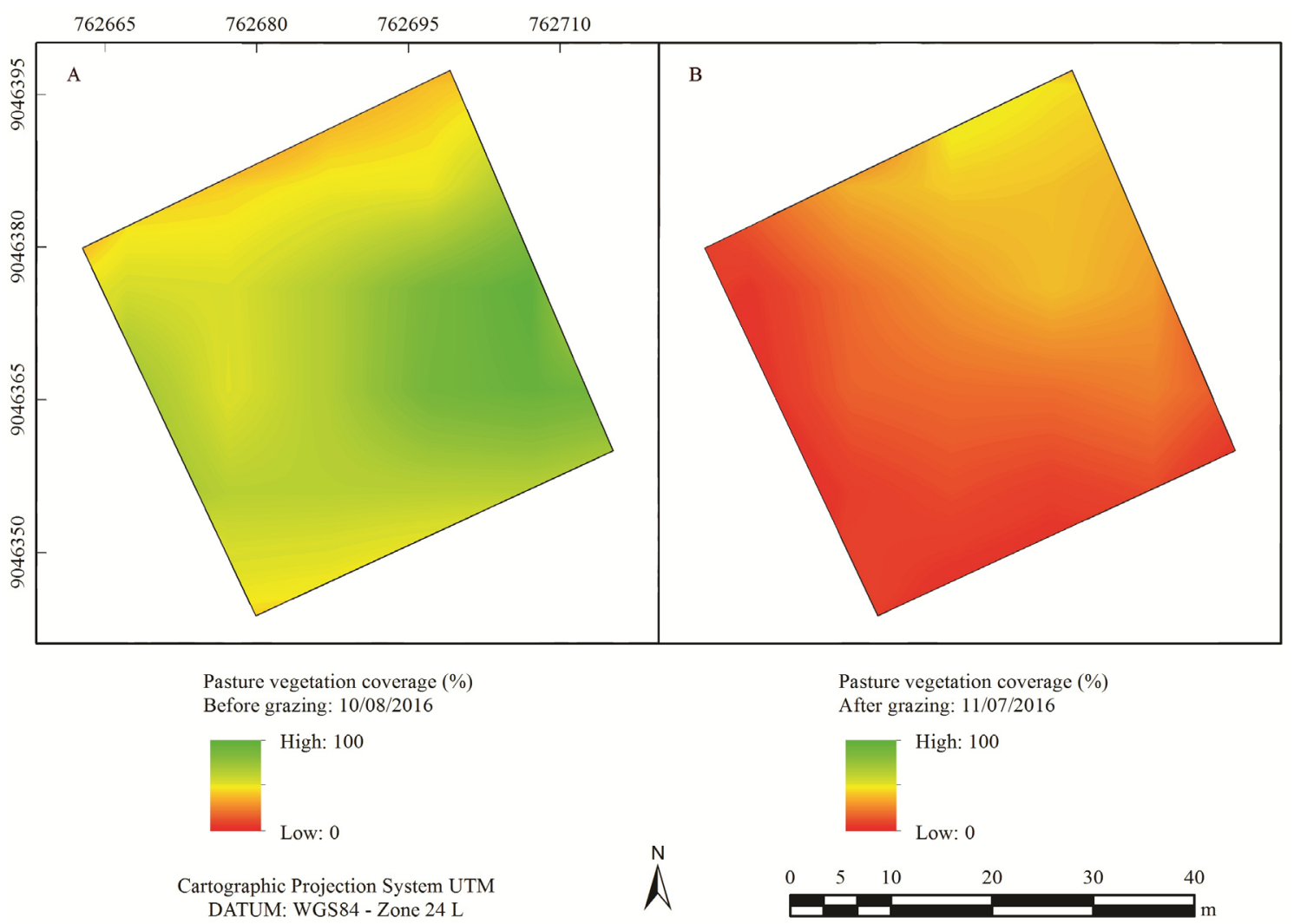

Figure 4. Spatial variation of pasture vegetation coverage in the study area, before (A) and after (B) grazing

and properties of sandy soils, noting that grazing decreased the vegetation cover, the above-ground biomass, and the root biomass.

In this context, Calegario et al. (2019), who assessed, via remote sensing, the intensity of land use exercised by pastures in the Rio Doce watershed, on the border of Minas Gerais and Espírito Santo, Brazil, found that $46.9 \%$ of grazed areas are severely degraded; and $96.6 \%$ of the entire area shows some degree of degradation.

However, Aguiar et al. (2017), when using time series (2000 - 2012) of images obtained by satellite to observe degradation processes in tropical pastures in nine Brazilian states, observed that of the 782 sampled areas, $26.6 \%$ suffered some type of intervention to improve pasture (renovation, grazing system, stocking rate, among others), $19.1 \%$ were in biological degradation, and $54.3 \%$ did not show any intervention or reduction in biomass in the analyzed period.

\section{Conclusions}

1. The continuous grazing associated with the pressure of the cattle trampling increased the density and the penetration resistance of the soil of the roots.

2. The remote sensing techniques allowed us to identify areas of preference for grazing of animals and the reduction of the pasture vegetation coverage after grazing.

\section{ACKNOWLEDGMents}

To the Fundação de Amparo à Ciência e Tecnologia do Estado de Pernambuco (FACEPE APQ-0465-5.03/14) for financial support for the development of this research and this study was financed in part by the Coordenação de Aperfeiçoamento de Pessoal de Nível Superior - Brasil (CAPES) - Finance Code 001.

\section{Literature Cited}

ABIEC- Associação Brasileira das Indústrias Exportadoras de Carnes (2018). Perfil da pecuária no Brasil: Relatório anual 2018. Available on: http://abiec.siteoficial.ws/images/upload/sumario-pt-010217. pdf. Accessed on: Nov. 2018.

Aguiar, D. A.; Mello, M. P.; Nogueira, S. F.; Gonçalves, F. G.; Adami, M.; Rudorff, B. F. T. Modis time series to detect anthropogenic interventions and degradation processes in tropical pasture. Remote Sensing, v.9, p.73, 2017. https://doi.org/10.3390/ rs9010073

Allen, R. G.; Tasumi, M.; Trezza, R.; Waters, R.; Bastiaanssen, W. SEBAL (surface energy balance algorithms for land). Advance training and users manual - Idaho Implementation, version, 1, 2002. p.97.

Bagarello, V.; Di Prima, S.; Iovino, M.; Provenzano, G. Estimating field-saturated soil hydraulic conductivity by a simplified Beerkan infiltration experiment. Hydrological Processes, v. 28, p.10951103, 2014. https://doi.org/10.1002/hyp.9649

Bastiaanssen, W. G. SEBAL-based sensible and latent heat fluxes in the irrigated Gediz Basin, Turkey. Journal of Hydrology, v. 229, p.87-100, 2000. https://doi.org/10.1016/S0022-1694(99)00202-4

Batista, P. H. D.; Almeida, G. L. P.; Pandorfi, H.; Tavares, U. E.; Melo, A. A. S.; Guiselini, C. Spatial variability of soil physical-hydric attributes under bovine trampling in agreste of Pernambuco State, Brazil. Acta Scientiarum. Agronomy, v. 41, p. 1-11, 2019. https:// doi.org/10.4025/actasciagron.v41i1.39594 
Bernardi, A. C. de C.; Grego, C. R.; Andrade, R. G.; Rabello, L. M.; Inamasu, R. Y. Spatial variability of vegetation index and soil properties in an integrated crop-livestock system. Revista Brasileira de Engenharia Agrícola e Ambiental, v.21, p.513-518, 2017. https:// doi.org/10.1590/1807-1929/agriambi.v21n8p513-518

Bonetti, J. A.; Paulino, H. B.; Souza, E. D.; Carneiro, M. A. C.; Silva, G. N. Influência do sistema integrado de produção agropecuária no solo e na produtividade de soja e braquiária. Pesquisa Agropecuária Tropical, v.45, p.104-112, 2015. https://doi. org/10.1590/1983-40632015v4529625

Brito, W. B. M.; Campos, M. C. C.; Mantovanelli, B. C.; Cunha, J. M.; Franciscon, U.; Soares, M. D. R. Spatial variability of soil physical properties in Archeological Dark Earths under different uses in Southern Amazon. Soil and Tillage Research, v.182, p. 103-111, 2018. https://doi.org/10.1016/j.still.2018.05.008

Calegario, A. T.; Pereira, L. F.; Pereira, S. B.; Silva, L. N. O. da; Araújo, U. L. de; Fernandes Filho, E. I. Mapping and characterization of intensity in land use by pasture using remote sensing. Revista Brasileira de Engenharia Agrícola e Ambiental, v.23, p.352-358, 2019. https://doi.org/10.1590/1807-1929/agriambi.v23n5p352-358

Deon, R. C.; Zilli, D.; Brandelero, G.; Machado, R. G. Compaction and water infiltration capacity of a cambisol by the traffic of machines and cattle trampling. Revista Ciência Agrícola, v.16, p.77-84, 2018. https://doi.org/10.28998/rca.v16i1.4088

Donagema, G. K., Campos, D. B., Calderano, S. B., Teixeira, W. G., Viana, J. M. Manual de métodos de análise de solo. Rio de Janeiro: Embrapa Solos. 2011. 272p. Documentos (INFOTECA-E)

Drusch, M.; Del Bello, U.; Carlier, S.; Colin, O.; Fernandez, V.; Gascon, F.; Hoersch, B.; Isola, C.; Laberinti, P.; Martimort, P.; Meygret, A.; Spoto, F.; Sy, O.; F.Marchese, F.; Bargellini, P. Sentinel-2: ESA's optical high-resolution mission for GMES operational services. Remote sensing of Environment, v.120, p.25-36, 2012. https://doi.org/10.1016/j.rse.2011.11.026

ESA - European Space Agency (2015). Sentinel-2 User Handbook. Available on: https://sentinels.copernicus.eu/ documents/247904/685211/Sentinel-2_User_Handbook. Accessed on: Jun. 2019.

Fernández-Manso, A.; Fernández-Manso, O.; Quintano, C. SENTINEL-2A red-edge spectral indices suitability for discriminating burn severity. International journal of applied earth observation and geoinformation, v.50, p.170-175, 2016. https://doi.org/10.1016/j.jag.2016.03.005

Fidalski, J.; Alves, S. J. Grazing height of brachiaria and stocking rate limited by soil physical properties three years into an integrated soybean crop-livestock system. Revista Brasileira de Ciência do Solo, v.39, p.864-870, 2015. https://doi. org/10.1590/01000683rbcs20140667

Gao, Q.; Li, Y. E.; Wan, Y.; Lin, E.; Xiong, W.; Jiangcun, W.; Li, W. Grassland degradation in Northern Tibet based on remote sensing data. Journal of Geographical Sciences, v.16, p.165-173, 2006. https://doi.org/10.1007/s11442-006-0204-1
Haverkamp, R., Arrúe, J. L., Vandervaere, J. P., Braud, I., Boulet, G., Laurent, J. P., Taha, A., Ross, P. J., Angulo-Jaramillo, R. Hydrological and thermal behaviour of the vadose zone in the area of Barrax and Tomelloso (Spain): Experimental study, analysis and modeling. Project UE n. EV5C-CT, 92, 1996. 90p.

Lassabatere, L.; Angulo-Jaramillo, R.; Soria Ugalde, J. M.; Cuenca, R.; Braud, I.; Haverkamp, R. Beerkan estimation of soil transfer parameters through infiltration experiments - BEST. Soil Science Society of America Journal, v.70, p. 521-532, 2006. https://doi. org/10.2136/sssaj2005.0026

Manning, J.; Cronin, G.; González, L.; Hall, E.; Merchant, A.; Ingram, L. The behavioural responses of beef cattle (Bos taurus) to declining pasture availability and the use of GNSS technology to determine grazing preference. Agriculture, v.7, p.45, 2017. https:// doi.org/10.3390/agriculture7050045

Niu, Y. J.; Yang, S. W.; Wang, G. Z.; Liu, L.; Du, G. Z.; Hua, L. M. Relation between species distribution of plant community and soil factors under grazing in alpine meadow. The Journal of Applied Ecology, v.28, p.3891-3898, 2017. https://doi.org/10.13287/j.1001-9332.201712.005

Oldoni, L. V.; Cattani, C. E. V.; Mercante, E.; Johann, J. A.; Antunes, J. F. G.; Almeida, L. Annual cropland mapping using data mining and OLI Landsat-8. Revista Brasileira de Engenharia Agrícola e Ambiental, v.23, p.952-958, 2019.

Pulido, M.; Schnabel, S.; Contador, J. F. L.; Lozano-Parra, J.; GómezGutiérrez, Á.; Brevik, E. C.; Cerdà, A. Reduction of the frequency of herbaceous roots as an effect of soil compaction induced by heavy grazing in rangelands of SW Spain. Catena, v. 158, p.381389, 2017. https://doi.org/10.1016/j.catena.2017.07.019

Reynolds, W. D.; Bowman, B. T.; Drury, C. F.; Tan, C. S.; Lu, X. Indicators of good soil physical quality: density and storage parameters. Geoderma, v. 110, p.131-146, 2002.

Stolf, R. Teoria e teste experimental de fórmulas de transformação dos dados de penetrômetro de impacto em resistência de solo. Revista Brasileira de Ciência do Solo, v.15, p.229-235, 1991.

van Klink, R.; Schrama, M.; Nolte, S.; Bakker, J. P.; Wallis De Vries, M. F; Berg, M. P. Defoliation and soil compaction jointly drive largeherbivore grazing effects on plants and soil arthropods on clay soil. Ecosystems, v.18, p.671-685, 2015. https://doi.org/10.1007/ s10021-015-9855-Z

Vasques, I. C.; Souza, A. A.; Morais, E. G.; Benevenute, P. A.; da Silva, L. D. C.; Homem, B. G.; Casagrande, D. R.; Silva, B. M. Improved management increases carrying capacity of Brazilian pastures. Agriculture, Ecosystems \& Environment, v.282, p.30-39, 2019. https://doi.org/10.1016/j.agee.2019.05.017

Warrick, A.W.; Nielsen, D.R. Spatial variability of soil physical properties in the field. In D. Hillel (ed.), Applications of soil physics. New York: Academic. 1980, p.319-344.

Zhang, J.; Zuo, X.; Zhou, X.; Lv, P.; Lian, J.; Yue, X. Long-term grazing effects on vegetation characteristics and soil properties in a semiarid grassland, Northern China. Environmental Monitoring and Assessment, v.189, p.216, 2017. https://doi.org/10.1007/ s10661-017-5947-x 